\title{
Identification and Ranking the Critical Success Factors of Business Incubator of Science and Technology Parks - A Case Study: Business Incubator of Baqiyatallah University of Medical Sciences
}

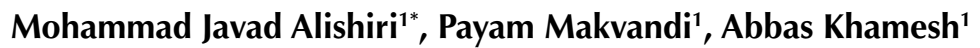 \\ ${ }^{1}$ Faculty of Management and Accounting, Islamic Azad University, Karaj Branch, Karaj, Iran \\ Corresponding Author: Mohammad Javad Alishiri, Faculty of Management and Accounting, Islamic Azad University, Karaj Branch, \\ Karaj, Iran. Tel: +98-9125644595, Email: mjalishiri1365@gmail.com
}

Received January 15, 2018; Revised April 2, 2018; Accepted April 6, 2018; Online Published June 20, 2018

\begin{abstract}
Introduction: As part of national program of innovation and a part of the science-oriented development plan, "science and technology" parks have an effective role in accelerating the process of turning ideas into real products and thus, the development of technology by providing necessary conditions for market-oriented research and merchandising the outcome of research. The purpose of the present research is to recognize, specify and prioritize vital elements in the success of development centers by concentrating on the case study of the development center of Baqiyatallah University of Medical Sciences (BMSU).

Materials and Methods: Primarily, In this regard, comprehensive literature review of more than 400 critical success indicators of parks and incubators were identified. Then, by integrating the overlays and the use of expert's opinion, initial screening was conducted. The numbers were classified which were limited to 43 indicators in 5 clusters (5 elements). In this study, the Friedman test was used to rank the following factors and also the critical success subfactors of business incubator of BMSU.

Results: Findings indicate that factor of "human resources" with value of 4.19 among other factors and index of "supporting the commercialization of research results" as a part of "support and services of incubators" with value of 7.94 among other indexes, allocated the first ranks.

Conclusions: The outcome of this research, with the leading role of the Science and Technology Center of BMSU, was done in order to be used in strategic management and macro-policy making of the University.

Keywords: Science and Technology Park, Business Incubator, Critical Success Factors

Citation: Alishiri MJ, Makvandi P, Khamesh A. Identification and ranking the critical success factors of business incubator of science and technology parks - a case study: business incubator of Baqiyatallah University of Medical Sciences. J Appl Biotechnol Rep. 2018;5(2):64-69. doi:10.29252/ jabr.05.02.05.
\end{abstract}

\section{Introduction}

Looking at the development process in countries with industrial innovations, it can be seen that the role of research parks is very important in this process. Indeed, one of the most significant factors in the growth of industrial innovation is the number and quality of research parks and their prosperity. The development of these research parks is one of the most important reasons which reminds us of the significance of an evaluation system in these research parks. ${ }^{1,2}$

Based on the definition of the international association of science and technology parks, a science park is an organization managing by experts and its major role is the enhancement of wealth in society through innovation and competition among existing knowledge-based companies and institutions. In order to achieve this goal, the science park triggers and manages the flow of science and technology in between universities, research and development institutions, private companies and the market and simplifies the growth of companies which rely on innovation, through these business incubations. Science parks also offer other services with high added value along with workspaces and high-quality convenience. ${ }^{3,4}$

Based on the national comprehensive scientific plan, national five-year development plan, the 20-year oversight plan of Iran in the year 1404 (2035 AD), Iran should move towards a science-oriented country with strong scientific and industrial infrastructures and industry-oriented scientific structure. The realization of this goal depends on the foundation and development of science-based and scienceoriented corporations in close relations with universities and academic centers. In fact, science and technology parks prepare and enlighten the way for progress. ${ }^{5,6}$

Nowadays, the main purpose of the foundation of research parks and research centers comes from the need

Copyright (C) 2018 The Author(s). This is an open-access article distributed under the terms of the Creative Commons Attribution License (http:// creativecommons.org/licenses/by/4.0), which permits unrestricted use, distribution, and reproduction in any medium, provided the original work is properly cited. 
for development, targeting the growth of technology and paving the way for scientific innovations and using creative and scientific potentials at universities, businesses and corporations. ${ }^{7}$

As a part of national program of innovation and scientificoriented economy research parks and scientific centers play an important role in accelerating the process of turning ideas into actual products and thus, the development of technology via providing necessary conditions for the growth of marketoriented research and commercialization the findings of these research. Assisting the development of small and mediocre businesses in the field of research-oriented economic activities, research parks help the growth of science and thus, the attraction of international investment, which would lead to the development and growth of a science-based economy in Iran. ${ }^{8,9}$

Furthermore, these research parks and development centers play significant roles by encouraging an atmosphere of healthy competition and innovation and transmission of technology among different sections via concentrating on the role of science and its dissemination among small firms, companies and corporations, market, and other centers., ${ }^{5,69}$

This study aimed to identify and rank the success factors of Baqiyatallah University of Medical Sciences (BMSU) incubator, a scale to assess success and planning to improve these factors.

\section{Materials and Methods}

The aim of the present study is an applied qualitative research and the method of cross-survey which was conducted in 2016 at the Baqiyatallah University of Medical Sciences. The study population included all universities of medical sciences expert in the field of science and technology parks, technology transfer management, assistants and consultants, managers and other employees in the university's incubator. In this case study sampling was not performed and the whole population was studied.

At first potential factors affecting the success of incubators and technology parks were identified and the primary framework for classification factors was designed. The library studies and literature review and interviews with experts in this field, success factors of the business incubator of science and technology parks were categorized in five groups including support and development, spatial factors, business and investment environment, park management and human resources. The questionnaire was prepared in two parts. The first part was demographic data related to participants in the survey and the second part was questioned relevant to other 5 groups which were classified according to the Likert scale. In this survey, the content and component (convergent validity) of the questionnaire were studied. The validity of the questionnaire was confirmed by supervisors, consultants, and three experts and also through studying the related books and articles. The validation was done via structural equation and confirmatory analysis factor by using the second version of SPSS Software:

- $\quad$ All load factors must be more than 0.5.

- Average variance extracted (AVE) must be more than 0.5.
The results are shown in Table 1 . As it can be seen in Table 1 all the load factors are more than 0.5 and AVE in all variables are above 0.5 which demonstrate the convergent validity.

The validation of the questionnaire was studied through Cronbach $\alpha$ and structural equation. In order to validate the questionnaire through Cronbach a method, firstly, 10 questionnaires were pretested. Then confidence factor was calculated using obtained data and SPSS software via Cronbach a method. It is worth mentioning the alpha coefficient under $60 \%$ usually considered as a weak coefficient, the domain of $70 \%$ is acceptable and more than $80 \%$ is in a proper domain. The confidence factor near 1 is considered as a good confidence factor. As the table demonstrates Cronbach $a$ for all factors are more than 0.8 which shows the validity of the questionnaire. By using structural equation and the second version of SPSS software and considering the Composite Reliability more than 0.7 , the questionnaire was evaluated. As it can be seen in the table, the CR in all variables is over 0.7 which shows composite reliability.

\section{Ethical Considerations}

This article does not contain any studies with human or animal models. Also this research approved by Islamic Azad University of Karaj Branch Ethics Committee.

\section{Results}

In Table 2 the data related to sex, age and academic degree of privates are shown.

Table 3 demonstrates the indicators related to support and service factors. In order to obtain this ranking, Friedman test was used. The $\mathrm{H} 0$ and $\mathrm{H} 1$ in Friedman test are as following:

$\mathrm{H} 0$ : The average ratings are the same.

$\mathrm{H} 1$ : At least 2 rates contain different means.

According to the Friedman test there is a significant difference between the two variables because significance level is under 0.05 ( $P$ value $=0.0001)$.

Ranking the critical success factors of business incubator of science and technology parks of BMSU are listed in Table 4 which Friedman test has been used for this purpose. The $\mathrm{H} 0$ and $\mathrm{H} 1$ in Friedman test are as following:

H0: The average rating is the same.

$\mathrm{H} 1$ : At least two rating means are different.

According to the Friedman test, it can be said that at least there is a significant factor between the two variables because the level of significance is lower than $0.05(P$ value $=0.0001)$. As it can be seen in the previous table, the human resources and indicators of location factors are regarded as the highest and lowest ratios affecting the successful factors of incubators respectively.

\section{Discussion}

According to findings of this study, in the factor of support and services of the incubator, the indicator of supporting the commercialization of research results and pre-incubator program are considered as the highest and lowest indicators influencing the successful factors of incubators respectively.

Based on obtained results of this study, in location factors, the indicator of supporting the commercialization of research 
Table 1. Load Factors, Significant Coefficients, Cronbach Alpha and Mean Test of a Society

\begin{tabular}{|c|c|c|c|c|c|c|c|c|}
\hline \multirow{2}{*}{ Indicators } & \multirow{2}{*}{ Item } & \multicolumn{3}{|c|}{ Factor Analysis Confirmatory } & \multicolumn{3}{|c|}{ Mean Test of a Society } & \multirow{2}{*}{ Cronbach $\alpha$} \\
\hline & & Load Factor & AVE & CR & Average & T Statistics & Summary of Situation & \\
\hline \multirow{12}{*}{$\begin{array}{l}\text { Support and } \\
\text { services of } \\
\text { incubators }\end{array}$} & SUP1 & 0.66 & \multirow{12}{*}{0.611} & \multirow{12}{*}{0.919} & \multirow{12}{*}{4.016} & \multirow{12}{*}{13.928} & \multirow{12}{*}{$\begin{array}{l}\text { Factors affecting the success of } \\
\text { incubators }\end{array}$} & \multirow{12}{*}{0.937} \\
\hline & SUP2 & 0.71 & & & & & & \\
\hline & SUP3 & 0.74 & & & & & & \\
\hline & SUP4 & 0.72 & & & & & & \\
\hline & SUP5 & 0.84 & & & & & & \\
\hline & SUP6 & 0.82 & & & & & & \\
\hline & SUP7 & 0.81 & & & & & & \\
\hline & SUP8 & 0.82 & & & & & & \\
\hline & SUP9 & 0.86 & & & & & & \\
\hline & SUP10 & 0.81 & & & & & & \\
\hline & SUP11 & 0.82 & & & & & & \\
\hline & SUP12 & 0.89 & & & & & & \\
\hline \multirow{8}{*}{ Location factors } & PLA1 & 0.81 & \multirow{8}{*}{0.537} & \multirow{8}{*}{0.871} & \multirow{8}{*}{3.711} & \multirow{8}{*}{11.583} & \multirow{8}{*}{$\begin{array}{l}\text { Factors affecting the success of } \\
\text { incubators }\end{array}$} & \multirow{8}{*}{0.853} \\
\hline & PLA2 & 0.78 & & & & & & \\
\hline & PLA3 & 0.69 & & & & & & \\
\hline & PLA4 & 0.76 & & & & & & \\
\hline & PLA5 & 0.68 & & & & & & \\
\hline & PLA6 & 0.71 & & & & & & \\
\hline & PLA7 & 0.75 & & & & & & \\
\hline & PLA8 & 0.77 & & & & & & \\
\hline \multirow{10}{*}{$\begin{array}{l}\text { Business } \\
\text { environment and } \\
\text { Investment } \\
\text { factors }\end{array}$} & BI 1 & 0.67 & \multirow{10}{*}{0.589} & \multirow{10}{*}{0.904} & & & & \\
\hline & $\mathrm{BI} 2$ & 0.87 & & & & & & \\
\hline & BI 3 & 0.79 & & & & & & \\
\hline & $\mathrm{BI} 4$ & 0.79 & & & & & & \\
\hline & BI 5 & 0.73 & & & 4051 & & Factors affecting the success of & \\
\hline & $\mathrm{BI} 6$ & 0.71 & & & 4.051 & 14.094 & incubators & 0.903 \\
\hline & $\mathrm{BI} 7$ & 0.89 & & & & & & \\
\hline & BI 8 & 0.89 & & & & & & \\
\hline & BI 9 & 0.84 & & & & & & \\
\hline & BI 10 & 0.72 & & & & & & \\
\hline & ORG1 & 0.91 & & & & & & \\
\hline & ORG2 & 0.89 & & & & & & \\
\hline & ORG3 & 0.94 & & & & & & \\
\hline Organization & ORG4 & 0.78 & & & & & & \\
\hline and management & ORG5 & 0.81 & 0.782 & 0.951 & 3.688 & 6.709 & Factors affecting the success of & 0.948 \\
\hline factors & ORG6 & 0.92 & & & & & & \\
\hline & ORG7 & 0.82 & & & & & & \\
\hline & ORG8 & 0.97 & & & & & & \\
\hline & ORG9 & 0.84 & & & & & & \\
\hline & HR1 & 0.83 & & & & & & \\
\hline Factors of human & HR2 & 0.74 & 0.621 & 0.845 & 4.388 & 23041 & Factors affecting the success of & 0.847 \\
\hline resources & HR3 & 0.79 & 0.021 & & & & incubators & \\
\hline & HR4 & 0.91 & & & & & & \\
\hline
\end{tabular}

results and indicator of existence of a base for research and development, activities in the field of advanced technology and proximity to communication lines (airplane, train, etc) and transport facilities are the highest and lowest indicators influencing the successful factors of incubators respectively. As the results depict, in factors related to the business environment and investment, the indicator of entrepreneurial and innovative spirit in order to increase the activities of incubators and indicators of access to financial resources and investment, having tax and investment incentives are the highest and lowest indicators influencing the successful factors of incubators respectively.
Table 2. Descriptive Statistics Demographic Variables

\begin{tabular}{llll}
\hline Variable & & No. & $\%$ \\
\hline \multirow{2}{*}{ Sex } & Male & 37 & 82.2 \\
& Female & 8 & 17.8 \\
Age & 30-40 years old & 9 & 20 \\
& 41-50 years old & 25 & 55.6 \\
& Over 51 years old & 11 & 24.4 \\
Educational status & Bachelor's degree & 5 & 11.11 \\
& Master's degree & 13 & 28.88 \\
& PhD & 27 & 60 \\
\hline
\end{tabular}


Table 3. Ranking the Indicators Related to Critical Success Factors of Business Incubator of Science and Technology Parks

\begin{tabular}{l} 
Indicators of Support and Service of Incubator Factors \\
\hline Pre-incubator program (before entering the incubator) \\
Common services such as legal advice, assistance \\
Access to specialized information and distribution of industrial information \\
Availability of technology transfer incubator for customers \\
Research equipment (laboratory, library, etc) \\
Availability of telecommunication systems, energy and advanced substructure \\
Supporting the sale of products, owning technical knowledge in target markets and existence of local markets in order to offer the
\end{tabular}
Average Rating

Providing the necessary security to prevent unauthorized access to the information within the park

\section{Indicators of Location Factors}

The use of renewable integrated energy resources

Access to urban centers and facilities

Regional Advantage, which is located in the center and easy access to the spaces and facilities with reasonable price and close to a big city

Proximity to communication lines (plane, train, etc) and transport facilities

A base for research and development activities, and activities in the field of technology

The presence of incubators and research institutes and having interaction

Access to components and service providers in the region

Factors Related to the Business Environment and Investment

Access to finance and good tax and investment incentives

Goals and vision of the organization as well as bright and detailed provisions of the laws and political regulations

Shared vision among stakeholders center for science and technology

Presence of big companies with high quality in incubator

Communication and support from a university, an institute or an entrepreneurship center 6.02

Attracting foreign direct investment using some facilities 5.97

Government, community and decision makers support 5.07

A network of entrepreneurs, partners and friends 5.14

Entrepreneurship and innovation spirit to enhance the activities of the incubator 6.12

Good reputation and proper image of incubator 5.52

\section{Indicators of Organization and Management Factors}

Owning a committed management team with specialized skills

\section{Indicators Related to Human Resource Factors}


Table 4. Ranking the Successful Factors of Incubators

\begin{tabular}{lcl}
\hline Ranking & Average Rating & Successful Factors of Incubators \\
\hline 1 & 4.19 & $\begin{array}{l}\text { Human resources factors } \\
2\end{array}$ \\
\hline 3 & 2.47 & $\begin{array}{l}\text { Factors related to the business environment } \\
\text { and investment }\end{array}$ \\
\hline 4 & 2.20 & Factor of support and services of incubators \\
\hline 5 & 2.16 & Location factors \\
\hline
\end{tabular}

These findings show that in organization and management factors, indicator of having skilled and committed management team and indicator of full-time management are the highest and lowest indicators influencing the successful factors of incubators respectively.

According to the results of this study, in human resources factors, expertise and specialty staff of research and development and indicator of creating new job opportunities for talented staff are the highest and lowest indicators influencing the successful factors of incubators respectively.

Also, the government and official's support and their longterm investment in these research parks are important factors in the development of these parks. Therefore, the support of officials and policy-makers are among the important elements in their success. This support is specifically important due to the dependent nature of the country's economy to the state. On the other hand, the decisions and policies of the state would definitely affect the function of research parks. Subsequently, officials support would encourage the supervisors of these parks to provide better and more efficacious services with more and better qualities. Therefore, all Business Incubator of science and technology parks must provide these services and requirements. Providing these services are part of the main tasks of parks and incubators on helping companies based in the park which park managers must develop the necessary arrangements in this case.

Amirahmadi and $\mathrm{Saff}^{10}$ in their studies proposed the idea of creating a real mission and strategy and the core program components contribute to strengthening the science parks and understanding the issues and expectations stakeholder for development of science and technology parks. Gay ${ }^{11}$ stated that responding to various stakeholders is one of the main keys in science and technology parks success. Monck and Peters ${ }^{12}$ also expressed that determining the role of technology parks in the regional and national development is the most vital factor. Also in a study by Bahari et al ${ }^{13}$ they recognition and prioritization of key elements in the success of "Research and Technology Parks" in Khorasan Razavi province. In their study, they concluded that key factors in the development of science-oriented institutes in terms of the production of technology respectively are human resources, the development of necessary infrastructure for the growth of technology, and the foundation of technology-oriented centers who are in touch with research parks. The importance and priority of these key factors of success can be a point of view for director and founder of the science park to succeed in creating and developing science and technology parks.

In addition, in a report by Soofi and Goodarzi ${ }^{5}$ it was concluded that management factors are the most important. Among the factors, having inferred strategic goals and specific plans, mastering managers in issues related to science and technology parks, the political atmosphere of the park in order to support the science and technology parks and its purposes and determine criteria for clear and formal admission, attendance, assessment and control the activities of companies based in the park are among the most important factors.

\section{Conclusions}

The factors, which were recognized and discussed in this research, are only a part of effective factors in the function of research and technology parks. The recognition and discussion of other factors by supervisors of these parks and operationalization of such findings, and the assessment of these parks would help the officials and policy-makers to use these assessments and findings in the development and growth of these parks and thus, would pave the way for more effective research parks via more investment and the allocation of better human and financial resources to these parks in order for them to play more effective roles in Iran's economy and the development of a science-based economy and economic activities in the future.

\section{Authors' Contributions}

All authors contributed equally to this research.

\section{Conflict of Interest Disclosures}

The authors declare they have no conflicts of interest.

\section{References}

1. Link An, Scott Jt. US science parks: the diffusion of an innovation and its effects on the academic missions of universities. Int J Ind Organ. 2003;21(9):1323-1356. Doi:10.1016/S01677187(03)00085-7.

2. Kharabsheh R. Critical success factors of technology parks in Australia. International Journal Of Economics And Finance. 2012;4(7):57-66. Doi:10.5539/ljef.v4n7p57

3. Somsuk N, Wonglimpiyarat J, Laosirihongthong T. Technology business incubators and industrial development: resource-based view. Industrial Management \& Data Systems. 2012;112(2):245267. Doi:10.1108/02635571211204281.

4. Henriques Ic, Sobreiro Va, Kimura H. Science and technology park: future challenges. Technol Soc. 2018;53:144-60. Doi:10.1016/J. techsoc.2018.01.009.

5. Soofi As, Goodarzi M. The Development of science and technology In Iran. New York: Palgrave Macmillan; 2017. Doi:10.1057/978-1137-57257-8.

6. Kusharsanto Zs, Pradita L. the important role of science and technology park towards indonesia as a highly competitive and innovative Nation. Procedia - Social And Behavioral Sciences 2016;227:545-552. Doi:10.1016/J.sbspro.2016.06.113.

7. Mansour Amh, Kanso L. Science Park Implementation - A Proposal For Merging Research And Industry In Developing Arab Countries. Hbrc Journal. 2017. Doi:10.1016/J.hbrcj.2017.06.002.

8. Gliga G, Evers N. Marketing challenges for high-tech smes. Innovative Marketing. 2010;6(3):104-112. 
9. Mc Cartan-Quinn D, Carson D. Issues which impact upon marketing in the small firm. Small Business Economics. 2003;21(2):201-213. Doi:10.1023/A:1025070107609.

10. Amirahmadi H, Saff G. Science parks: a critical assessment. J Plan Lit. 1993; 8(2):107-123. Doi:10.1177/088541229300800201

11. Gay K. The Science Park Evaluation Handbook, Science Park Evaluation and Goal Oriented Project-Planning Section. European Innovation Monitoring System (Eims); 1996.
12. Monck C, Peters K. Science parks as an instrument of regional competitiveness: measuring success and impact. IASP 2009 Conference; Taiwan; 2009.

13. Bahari A, Moody B, Yaghoobi N, Alamolhodaei Sh. Identification and prioritization of critical success factors of Khorasan Razavi Science and Technology Park. Roshd-E-Fanavari. 2012;8(30):1321. (Persian). 